\title{
ANALISIS PERTUMBUHAN DAN KARAKTER FISIOLOGI TANAMAN KEDELAI PADA PENGOLAHAN LAHAN, PENGKLENTEKAN DAUN TEBU DAN PUPUK CAIR HUMAKOS PADA SISTEM TUMPANGSARI TEBU KEDELAI
}

\author{
ANALYSIS OF GROWTH AND CHARACTER OF PHYSIOLOGY OF \\ SOYBEAN PLANTS IN LAND PROCESSING, SUGARCANE LEAF PICKING \\ AND HUMAKOS LIQUID FERTILIZER IN INTERCROPPING SYSTEM \\ SUGERCANE AND SOYBEAN
}

\author{
Wiwit Widiarti dan Iftitah Azzahra*) \\ *) Fakultas Pertanian Universitas Muhammadiyah Jember \\ Email :wiwit.widiarti@unmuhjember.ac.id
}

\begin{abstract}
ABSTRAK
Penelitian ini bertujuan untuk mengetahui pertumbuhan dan karakter fisiologi tanaman kedelai pada pengolahan lahan, pengklentekan daun tebu dan pemberian pupuk cair humakos pada sistem tumpang sari tebu kedelai. Penelitian dilaksanakan di kebun percobaan Fakultas Pertanian Universitas Muhammadiyah Jember bertempat di Jalan Karimata, Kecamatan Sumbersari, Kabupaten Jember. Penelitian dimulai pada 10 Desember 2018 sampai 10 Maret 2019 dengan ketinggian tempat +89 meter diatas permukaan laut (dpl). Rancangan yang digunakan adalah Split-Split Plot yang disusun dengan percobaan factorial terdiri dari tiga faktor yaitu Petak Utama, Pengolahan Lahan (L), sebagai Anak Petak, Pengklentekan Daun Tebu (P), dan sebagai Anak-Anak Petak, Pemberian Pupuk Cair Humakos (H), masing-masing perlakuan diulang 2 kali. Variabel yang diamati : nisbah luas daun, laju asimilasi bersih, laju pertumbuhan tanaman, luas daun spesifik, nilai kesetaraan lahan dan indek panen. Hasil penelitian menunjukkan pengolahan lahan (L) berbeda nyata pada variabel pengamatan luas daun spesifik dan tidak berbeda nyata pada semua variabel. Pengklentekan daun tebu (P) tidak berbeda nyata pada semua variabel. Pemberian pupuk cair humakos $(\mathrm{H})$ berbeda nyata pada variabel nilai kesetaraan lahan (nkl), dan tidak berbeda nyata pada semua variabel. Interaksi pengolahan lahan dan pengklentekan daun tebu (LxP) berbeda nyata pada variabel laju asimilasi bersih dan tidak berbeda nyata pada semua variabel. Interaksi pengolahan lahan dan pemberian pupuk cair humakos $(\mathrm{LxH})$ berbeda nyata pada variabel luas daun spesifik dan indeks panen serta tidak berbeda nyata pada semua variabel. Interaksi pengklentekan daun tebu dan pemberian pupuk cair humakos $(\mathrm{PxH})$ berbeda nyata pada variabel laju pertumbuhan tanaman, luas daun, dan tidak berbeda nyata pada semua variabel. Interaksi pengolahan lahan, pengklentekan daun tebu dan pemberian pupuk cair humakos $(\mathrm{LxPxH})$ tidak berbeda nyata pada semua variabel pengamatan.
\end{abstract}

Kata Kunci : Pengolahan Lahan, Pengklentekan Daun Tebu, Pupuk Cair Humakos

\section{ABSTRACT}

This study aims to determine the growth and physiological character of soybean plants in land processing, sugarcane leaf picking and humakos liquid fertilizer application in the intercropping sytem of soybean. The study was condauted in the Experimental Garden of Agriculture Faculty, Universitas Muhammadiyah Jember, at Karimata No. 49 Sumbersari Jember. The study began on Desember 10 $0^{\text {th }}, 2018$ until March 10 ${ }^{\text {th }}, 2019$ with a height of + 89 meters above sea level. The design used is Split-split plot which was arranged by Factorial Experiment consisting on three factors, namely Main Plot, Land Processing (L), as Sub Plots, sugarcane leaf picking $(P)$ and Sub-sub plot, Giving of humakos liquid 
fertilizer $(H)$, each treatment was repeated 2 times. Observed variable : leaf area ratio, net assimilation rate, plant growth rate, specific leaf area. Land equality value and harvest index. The result showed that land processing $(L)$ was significantlydifferent in the observation variables of specific leaf area and not significantly different in all variables. Humakos liquid fertilizer application $(H)$ was significantly different in the land equality value variable, and not significantly different in all variables. The interaction between land processing and suger cane leaf picking $\left(\begin{array}{lll}L & x & P\end{array}\right)$ was significanly different on the net assimilation rate variable and not significanly different on all variables. The interaction between land processing and the application of humakos liquid fertilizer $(L \times H)$ was significanly different in the spesific leaf area variable and harvest index and not significanly different in all variables. The interaction between sugarcane leaf picking and the application of humakos liquid fertilizer $(P x H)$ was significanly different in the variable plant growt rate, leaf area, and not significanly different in all variables. The interaction between land processing, sugarcane leaf picking and giving humakos liquid fertilizer $(L \times P \times H)$ were not significanty different in all observational variables.

Keywords : Land precessing, sugarcane leaf picking, homakos liquid fertilizer.

\section{PENDAHULUAN}

Kedelai (Glycine max L.) termasuk salah satu jenis tanaman legum kacang-kacangan yang sangat potensial sebagai sumber protein nabati. Kedudukannya sangat penting dalam kebutuhan pangan, karena banyak dikonsumsi oleh masyarakat dan mengandung nilai gizi yang tinggi. Sebagai sumber protein kedelai menempati urutan pertama diantara tanaman kacang-kacangan (Adisarwanto, 2014). Untuk meningkatkan produksi kedelai perlu dilakukan berbagai macam usaha seperti intensifikasi lahan, melalui pemberian unsur hara mikro, pengaturan irigasi maupun pengolahan tanah.

Tindakan pengolahan tanah bertujuan unuk meningkatkan aerasi tanah, sehingga perkembangan akar tanaman dalam tanah lebih baik dan mengurangi pemadatan tanah. Pengolahan tanah yang berlebihan dapat membuat sifat olah yang jelek serta menurunkan ruang pori. Untuk memperkecil pengaruh yang merugikan dari tindakan pengolahan tanah, maka pengolahan tanah dilakukan secukupnya saja. Hal ini didukung oleh Andrianto dan Indarto (2004) yang menjelaskan bahwa perlu tidaknya tanah diolah harus dilihat dari kepadatan tanah, kekuatan tanah, dan tingkat aerasi.

Usahatani tumpang sari ialah dua jenis tanaman atau lebih yang diusahakan bersama-sama pada satu tempat dalam waktu yang sama, dengan jarak tanam yang teratur, sehingga dikenal dengan istilah yang disebut rotasi tanaman. Pola tanam ini dianggap mampu mengurangi resiko kerugian yang disebabkan fluktuasi harga, serta menekan biaya operasional seperti tenaga kerja dan pemeliharaan tanaman. Selain itu, perkembangan pola tanam tumpang sari diharapkan mampu mendukung program pemerintah dalam memperkuat ketahanan pangan nasional (Dompasa, 2014).

\section{METODE PENELITIAN}

Penelitian ini dilaksanakan di kebun percobaan Fakultas Pertanian Universitas Muhammadiyah Jember yang bertempat di Jln. Karimata No 49, Kecamatan Sumbersari, Kabupaten Jember. Di mulai pada tanggal 10 Desember 2018 sampai 10 Maret 2019 dengan ketinggian tempat +89 meter diatas permukaan laut (dpl). Penelitian ini dirancang dengan menggunakan rancangan dasar Rancangan Petak-Petak Terbagi (RPPT) atau Split Split Plot 
yang disusun dengan percobaan factorial yang terdiri dari tiga faktor yaitu sebagai Petak Utama, Pengolahan Lahan (L) ; singkal (L1), singkal+rotari (L2) dan sinkal+rotari+rotari (L3) Anak Petak, Pengklentekan Daun Tebu (P) ; 45 hst (P1), 60 hst (P2) dan 80 hst (P3) dan Anak-anak Petak, Pemberian Pupuk Cair Humakos (H) ; 4 liter/ha (H1), 8 liter/ha (H2) dan 12 liter/ha (H3) masing-masing perlakuan diulang 2 kali. Variabel yang diamati meliputi : nisbah luas daun, laju asimilasi bersih, laju pertumbuhan tanaman, luas daun spesifik, nilai kesetaraan lahan dan indek panen.

\section{HASIL DAN PEMBAHASAN}

Hasil penelitian tentang analisis pertumbuhan dan karakter fisiologi tanaman kedelai pada pengolahan lahan, pengklentekan daun tebu dan pemberian pupuk cair humakos pada sistem tumpangsari tebu kedelai, menggunakan parameter nisbah luas daun, laju asimilasi bersih, laju pertumbuhan tanaman, luas daun spesifik, nilai kesetaraan lahan (NKL), dan indeks panen sebagai parameter pengamatan. Hasil pengamatan dianalisis dengan Rangkuman hasil ANNOVA terhadap semua perlakuan dapat dilihat pada Tabel 1.

Tabel 1. Rangkuman Hasil ANOVA Terhadap Semua Variabel Pengamatan

\begin{tabular}{|c|c|c|c|c|c|c|c|}
\hline \multirow[b]{2}{*}{ Variabel Pengamatan } & \multicolumn{7}{|c|}{ F - Hitung } \\
\hline & $\begin{array}{l}\text { Pengo } \\
\text { lahan } \\
\text { Lahan } \\
\text { (L) }\end{array}$ & $\begin{array}{c}\text { Pengklen } \\
\text { tekan } \\
\text { Daun } \\
\text { Tebu (P) }\end{array}$ & $\begin{array}{c}\text { Pupuk } \\
\text { Huma } \\
\text { kos }(\mathrm{H})\end{array}$ & $(\mathrm{LxP})$ & $(\mathrm{LxH})$ & $\mathrm{PxH}$ & $\mathrm{LxPxH}$ \\
\hline Nisbah Luas daun 1 Bst & $1,21 \mathrm{~ns}$ & $2,42 \mathrm{~ns}$ & $1,25 \mathrm{~ns}$ & $0,82 \mathrm{~ns}$ & $2,08 \mathrm{~ns}$ & $2,75 \mathrm{~ns}$ & $0,61 \mathrm{~ns}$ \\
\hline Nisbah Luas daun 2 Bst & $2,40 \mathrm{~ns}$ & 1,50 & $0,79 \mathrm{~ns}$ & $0,51 \mathrm{~ns}$ & $0,83 \mathrm{~ns}$ & $0,87 \mathrm{~ns}$ & $0,28 \mathrm{~ns}$ \\
\hline Laju Asimilasi Bersih & $5,25 \mathrm{~ns}$ & $4,70 \mathrm{~ns}$ & $0,25 \mathrm{~ns}$ & $5,17 * *$ & $1,55 \mathrm{~ns}$ & $1,04 \mathrm{~ns}$ & $1,79 \mathrm{~ns}$ \\
\hline $\begin{array}{l}\text { Laju Pertumbuhan } \\
\text { Tanaman }\end{array}$ & $1,08 \mathrm{~ns}$ & $0,98 \mathrm{~ns}$ & $1,58 \mathrm{~ns}$ & $1,22 \mathrm{~ns}$ & $0,61 \mathrm{~ns}$ & $3,05 *$ & $0,14 \mathrm{~ns}$ \\
\hline Luas daun spesifik $1 \mathrm{BST}$ & $1,80 *$ & 0,11 & $0,07 \mathrm{~ns}$ & $0,41 \mathrm{~ns}$ & $0,21 \mathrm{~ns}$ & $0,0046 \mathrm{~ns}$ & $0,20 \mathrm{~ns}$ \\
\hline Luas daun spesifik 2 BST & $1,22 \mathrm{~ns}$ & 1,07 & $0,95 \mathrm{~ns}$ & $0,87 \mathrm{~ns}$ & $3,66 *$ & $0,18 \mathrm{~ns}$ & $0,84 \mathrm{~ns}$ \\
\hline $\begin{array}{l}\text { Nilai Kesetaraan Lahan } \\
\text { (NKL) }\end{array}$ & $2,20 \mathrm{~ns}$ & 0,14 & $5,07 *$ & $0,42 \mathrm{~ns}$ & $2,65 \mathrm{~ns}$ & $0,43 \mathrm{~ns}$ & $1,66 \mathrm{~ns}$ \\
\hline Indeks Panen & $0,49 \mathrm{~ns}$ & $0,66 \mathrm{~ns}$ & $0,11 \mathrm{~ns}$ & $0,22 \mathrm{~ns}$ & $3,62 *$ & $2,59 \mathrm{~ns}$ & $0,55 \mathrm{~ns}$ \\
\hline
\end{tabular}

Keterangan :* : Berbeda nyata, **: Berbeda sangat nyata, ns : Tidak berbeda nyata

Hasil analisis ragam (Tabel 1) menunjukkan perlakuan pengolahan lahan memberikan pengaruh berbeda nyata pada variabel pengamatan luas daun spesifik umur 1 BST dan tidak berbeda nyata pada semua variabel pengamatan. Perlakuan pengklentekan daun tebu tidak berbeda nyata pada semua variabel. Perlakuan pemberian humakos memberikan pengaruh berbeda nyata pada variabel nilai kesetaraan lahan (nkl) dan tidak berbeda nyata pada semua variabel pengamatan.

Interaksi perlakuan pengolahan lahan dan pengklentekan daun tebu (LxP) memberi pengaruh berbeda sangat nyata pada variabel laju asimilasi bersih dan berpengaruh tidak berbeda nyata pada semua varibael pengamatan. Interaksi pengolahan lahan dan pemberian humakos (LxH) memberi pengaruh berbeda nyata pada variabel luas daun spesifik umur 2 BST dan indeks panen serta tidak berbeda nyata pada semua variabel pengamatan. Interaksi pengklentekan daun tebu dan pemberian humakos $(\mathrm{PxH})$ memberi pengaruh berbeda nyata pada variabel laju pertumbuhan tanaman, dan pengaruh tidak berbeda nyata pada semua variabel pengamatan. Interaksi pengolahan lahan, pengklentekan daun tebu dan pemberian humakos $(\mathrm{LxPxH})$ berpengaruh tidak berbeda nyata pada semua variabel pengamatan. 


\section{Nisbah Luas Daun}

Tabel 1 menunjukkan bahwa analisis ragam nisbah luas daun tanaman kedelai berpengaruh tidak berbeda nyata pada semua perlakuan pengolahan lahan (L), pengklentekan daun tebu $(\mathrm{P})$, pemberian pupuk cair humakos $(\mathrm{H})$, pengolahan lahan dan pengklentekan daun tebu (LP), pengolahan lahan dan pemberian pupuk cair humakos (LH), pengklentekan daun tebu dan pemberian pupuk cair humakos (PH), dan pengolahan lahan, pengklentekan daun tebu dan pemberian pupuk cair humakos (LPH).

Rata-rata nisbah luas daun yang di pengaruhi oleh interaksi pengolahan lahan, pengklentekan daun tebu dan pemberian pupuk cair humakos (LPH) pada umur 1 dan 2 BST dapat dilihat pada Gambar 1.

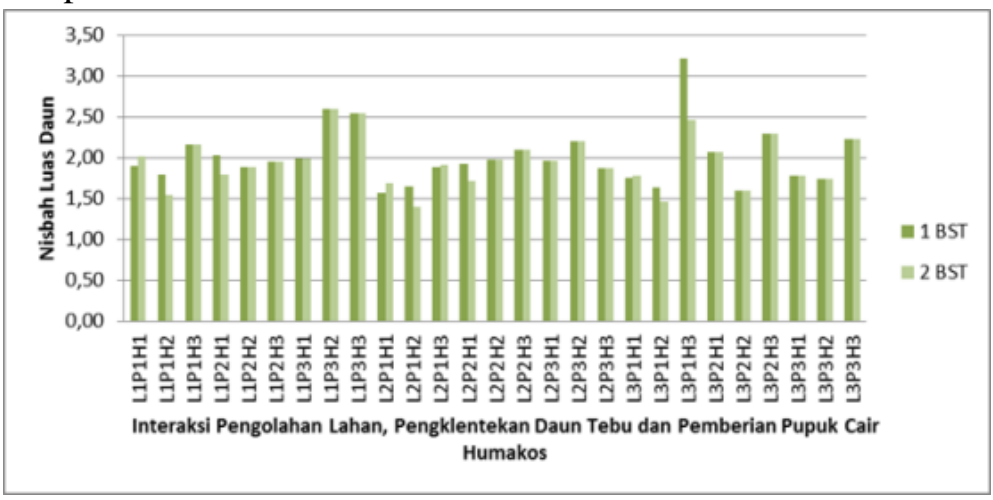

Gambar 1. Rata-rata interaksi pengolahan lahan, pengklentekan daun tebu dan pemberian pupuk cair humakos pada nisbah luas daun tanaman kedelai pada umur 1 dan 2 BST.

Gambar 1 menunjukkan rata-rata nisbah luas daun umur 1 BST tertinggi pada interaksi pengolahan lahan L3 (Singkal+Rotari+Rotari), pengklentekan daun tebu P1 (45 hst) dan pemberian pupuk cair humakos $\mathrm{H} 3$ (12 liter/Ha) L3P1H3 yaitu 3,21 dan rata-rata nisbah luas daun terendah pada interaksi pengolahan lahan L2 (Singkal+Rotari), pengklentekan daun tebu P1 (45 hst) dan pemberian pupuk cair humakos $\mathrm{H} 2$ (8 liter/Ha) L2P1H2 yaitu 1,57. Sedangkan pada umur 2 BST rata-rata tertinggi pada interaksi pengolahan lahan L1 (Singkal), pengklentekan daun tebu P3 (80 hst) dan pemberian pupuk cair humakos $\mathrm{H} 2$ (60 ml humakos+4 liter air) $\mathrm{L} 1 \mathrm{P} 3 \mathrm{H} 2$ yaitu 2,59 dan rata-rata terendah pada interaksi pengolahan lahan L2 (Singkal+Rotari), pengklentekan daun tebu P1 (45 hst) dan pemberian pupuk cair humakos $\mathrm{H} 1$ (40 ml humakos +2 liter air) L2P1H2 yaitu 1,40.

\section{Laju Asimilasi Bersih}

Berdasarkan analisis ragam (Tabel 1), terhadap laju asimilasi bersih pada tanaman kedelai menunjukkan bahwa perlakuan pengolahan lahan (L), pengklentekan daun tebu (P), pemberian pupuk cair humakos $(\mathrm{H})$ tidak berbeda nyata, sedangkan interaksi antara pengolahan lahan dan pengklentekan daun tebu (LP) berpengaruh berbeda nyata pada laju asimilasi bersih pada tanaman kedelai dan interaksi antara pengolahan lahan dan pemberian pupuk cair humakos (LH), pengklentekan daun tebu dan pemberian pupuk cair humakos $(\mathrm{PH})$ serta interaksi pengolahan lahan, pengklentekan daun tebu dan pemberian pupuk cair humakos (LPH) berpengaruh tidak berbeda nyata pada variabel laju asimilasi bersih tanaman kedelai.

Pada perlakuan interaksi pengolahan lahan dan pengklentekan daun tebu (LP) terhadap pengamatan laju asimilasi bersih berpengaruh berbeda nyata. Adapun rata-rata laju 
asimilasi bersih yang dipengaruhi oleh perlakuan interaksi pengolahan lahan dan pengklentekan daun tebu disajikan pada Tabel 2.

Tabel 2. Rata-rata Laju Asimilasi Bersih Pada Interaksi Perlakuan Pengolahan Lahan Dan Pengklentekan Daun Tebu.

\begin{tabular}{cccc}
\hline & P1 & P2 & P3 \\
\hline L1 & $0,19 \mathrm{bp}$ & $0,53 \mathrm{bp}$ & $0,84 \mathrm{ap}$ \\
L2 & $0,23 \mathrm{bp}$ & $0,49 \mathrm{bp}$ & $0,99 \mathrm{ap}$ \\
L3 & $0,41 \mathrm{bq}$ & $0,92 \mathrm{aq}$ & $0,77 \mathrm{aq}$ \\
\hline
\end{tabular}

Keterangan : Angka rata-rata pada baris yang sama yang dikuti oleh huruf yang sama a,b,c yang sama dan angka rata-rata pada kolom yang sama yang di ikuti huruf p,q,r yang sama menunjukkan tidak berbeda nyata pada Uji DMRT 5\%.

Tabel 2, hasil rata-rata laju asimilasi bersih pada interaksi pengolahan lahan dan pengklentekan daun tebu setelah diuji lanjut DMRT 5\%, interaksi perlakuan pengolahan lahan dan pengklentekan daun tebu pada rata-rata baris yang sama di ikuti hururf a,b,c (L1P1) yaitu 0,19 dan (L1P2) yaitu 0,53 tidak berbeda nyata tetapi berbeda nyata pada interaksi (L1P3) yaitu 0,84, interaksi (L2P1) yaitu 0,23 dan (L2P2) yaitu 0,49 tidak berbeda nyata tetapi berbeda nyata pada interaksi (L2P3) yaitu 0,99 , interaksi (L3P2) yaitu 0,92 dan (L3P3) yaitu 0,77 tidak berbeda nyata tetapi berbeeda nyata pada interaksi (L3P1) yaitu 0,41 . Sedangkan pada interaksi pengolahan lahan dan pengklentekan daun tebu rata-rata pada kolom yang sama di ikuti oleh huruf p, q, r interaksi (L1P1) yaitu 0,19, (L2P1) yaitu 0,23 tidak berbeda nyata tetapi berbeda nyata dengan (L3P1) yaitu 0,41 , interaksi (L1P2) yaitu 0,53 dan (L2P2) yaitu 0,49 tidak berbeda nyata tetapi berbeda nyata pada (L3P2) yaitu 0,92 , interaksi (L1P3) yaitu 0,84 , (L2P3) yaitu 0,99 tidak berbeda nyata tetapi berbeda nyata dengan (L3P3) yaitu 0,77 pada semua interaksi. Hal ini diduga karena pertumbuhan tanaman masih kecil, daun-daun yang terdapat pada tanaman tersebut semua terekspos pada radiasi matahari langsung sehingga kecepatan asimilasi $\mathrm{CO}_{2}$ meningkat yang mengakibatkan nilai LAB tinggi (Pujisiswanto dan Pangaribuan. 2008). Berdasarkan hasil analisis ragam (Tabel 1), bahwa tidak berpengaruh nyata dalam interaksi pengolahan lahan dan pemberian pupuk cair humakos terhadap variabel laju asimilasi bersih.

Adapun rata-rata laju asimilasi bersih oleh interaksi pengolahan lahan, pengklentekan daun tebu dan pupuk cair humakos pada tanaman kedelai disajikan pada Gambar 2.

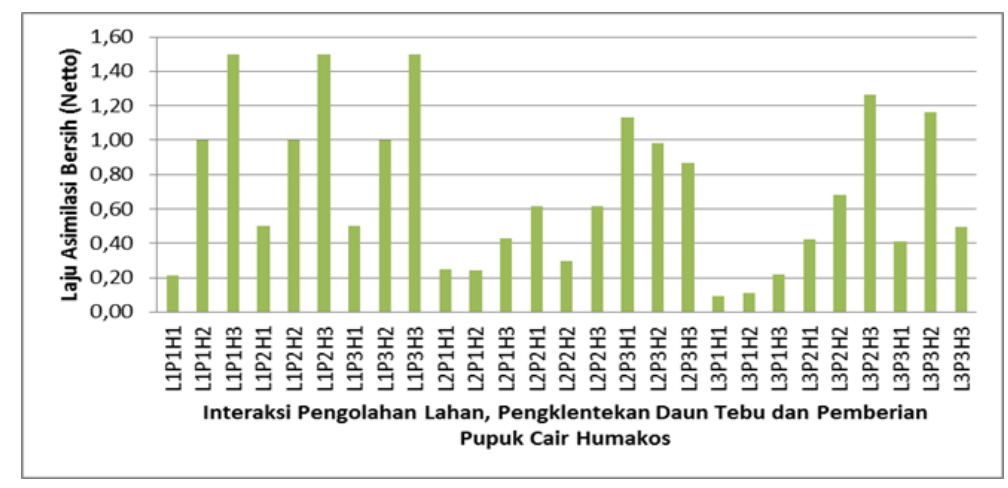

Gambar 2. Rata-rata interaksi pengolahan lahan, pengklentekan daun tebu dan pemberian pupuk cair humakos pada laju asimilasi bersih tanaman kedelai. 
Gambar 2, rata-rata laju asilmilasi bersih tertinggi terdapat pada interaksi pengolahan lahan L1 (Singkal), pengklentekan daun tebu P3 (80 hst) dan pemberian pupuk cair humakos $\mathrm{H} 3$ (12 liter/Ha) L1P3H3 yaitu 1,50 sedangkan rata-rata laju asimilasi bersih terendah pada interaksi pengolaahan lahan L3 (Singkal + Rotari + Rotari), pengklentekan daun tebu P1 (45 hst) dan pemberian pupuk cair humakos H1 (4 liter/Ha) L3P1H1 yaitu 0,09 .

\section{Laju Pertumbuhan Tanaman}

Berdasarkan analisis ragam (Tabel 1) terhadap laju pertumbuhan tanaman pada tanaman kedelai menunjukkan bahwa perlakuan pengolahan lahan, pengklentekan daun tebu, pemberian pupuk cair humakos, interaksi pengolahan lahan dan pengklentekan daun tebu, interaksi pengolahan lahan dan pemberian pupuk cair humakos, interaksi pengolahan lahan, pengklentekan daun tebu dan pemberian pupuk cair humakos berpengaruh tidak nyata, tetapi berpengaruh nyata pada interaksi pengklentekan daun tebu dan pemberian pupuk cair humakos, pada variabel laju pertumbuhan tanaman.

Berdasarkan Tabel 1 hasil analisis ragam terhadap laju pertumbuhan tanaman menunjukkan bahwa interaksi pengklentekan daun tebu dan pemberian pupuk cair humakos berpengaruh nyata terhadap variabel pengamatan laju pertumbuhan tanaman. Adapun ratarata laju pertumbuhan tanaman yang dipengaruhi oleh interaksi pengklentekan daun tebu dan pemberian pupuk cair humakos disajikan pada Tabel 3 .

Tabel 3. Rata-Rata Interaksi Pengklentekan Daun Tebu Dan Pemberian Pupuk Cair Humakos Pada Variabel Laju Pertumbuhan Tanaman.

\begin{tabular}{cccc}
\multicolumn{5}{c}{ H1 } & H2 & H3 \\
\hline P1 & $0,13 \mathrm{ap}$ & $0,12 \mathrm{ap}$ & $0,07 \mathrm{bq}$ \\
P2 & $0,07 \mathrm{bq}$ & $0,11 \mathrm{aq}$ & $0,10 \mathrm{ap}$ \\
P3 & $0,13 \mathrm{ap}$ & $0,12 \mathrm{ap}$ & $0,09 \mathrm{bp}$ \\
\hline
\end{tabular}

Keterangan : Angka rata-rata pada baris yang sama yang dikuti oleh huruf yang sama abc yang sama dan angka rata-rata pada kolom yang sama yang diikuti huruf $p, q, r$ yang sama menunjukkan tidak berbeda nyata pada Uji DMRT 5\%.

Tabel 3. hasil rata-rata laju pertumbuhan tanaman pada interaksi pengolahan lahan dan pengklentekan daun tebu setelah diuji lanjut DMRT 5\%, interaksi perlakuan pengklentekan daun tebu dan pemberian pupuk humakos pada rata-rata baris yang di ikuti huruf a,b,c yang sama menunjukkan tidak berbeda nyata (P1H1) yaitu 0,13 dan (P1H2) yaitu 0,12 tidak berbeda nyata tetapi berbeda nyata dengan $(\mathrm{P} 1 \mathrm{H} 3)$ yaitu 0,07 , interaksi $(\mathrm{P} 2 \mathrm{H} 2)$ yaitu 0,11 dan $(\mathrm{P} 2 \mathrm{H} 3)$ yaitu 0,10 tidak berbeda nyata tetapi berbeda nyata pada interaksi (P2H1) yaitu 0,07, interaksi $(\mathrm{P} 3 \mathrm{H} 1)$ yaitu 0,13 dan $(\mathrm{P} 3 \mathrm{H} 2)$ yaitu 0,12 tidak berbeda nyata tetapi berbeda nyata pada interaksi (P3H3) yaitu 0,09. Sedangkan pada interaksi pengklentekan daun tebu dan pemberian pupuk cair humakos pada rata-rata kolom yang diikuti oleh huruf $\mathrm{p}, \mathrm{q}, \mathrm{r}$ yang sama menunjukkan tidak berbeda nyata interaksi (P1H1) yaitu 0,13 dan $(\mathrm{P} 3 \mathrm{H} 1)$ yaitu 0,13 tidak berbeda nyata tetapi berbeda nyata pada interaksi $(\mathrm{P} 2 \mathrm{H} 1)$ yaitu 0,07 , interaksi $(\mathrm{P} 1 \mathrm{H} 2)$ yaitu $0,12,(\mathrm{P} 2 \mathrm{H} 2)$ yaitu 0,10 dan interaksi ( $\mathrm{P} 3 \mathrm{H} 2)$ yaitu 0,12 tidak berbeda nyata, interaksi $(\mathrm{P} 1 \mathrm{H} 3)$ yaitu 0,07 dan $(\mathrm{P} 3 \mathrm{H} 3)$ yaitu 0,9 tidak berbeda nyata tetapi berbeda nyata pada interaksi (P2H3) yaitu 0,10. Hal ini menunjukkan bahwa antara perlakuan pengklentekan daun tebu dan pemberian pupuk cair humakos karena adanya persaingan tanaman pada jarak tanam. Taufik dan Sundari (2012), 
mengatakan bahwa jarak tanam sangat menentukan tingginya laju pertumbuhan dan tingkat produktivitas.

Adapun rata-rata laju pertumbuhan tanaman yang dipengaruhi oleh interaksi pengolahan lahan, pengklentekan daun tebu dan pemberian pupuk cair humakos disajikan pada Gambar 3.

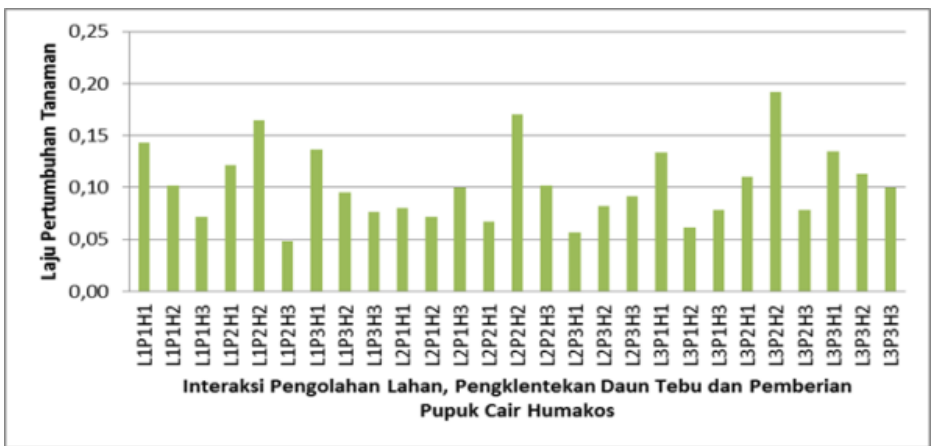

Gambar 3. Rata-rata interaksi pengolahan lahan, pengklentekan daun tebu dan pemberian pupuk cair humakos pada pertumbuhan tanaman kedelai.

Gambar 3 rata-rata laju pertumbuhan tanaman tertinggi terdapat pada interaksi pengolahan lahan L3 (Singkal+Rotari+Rotari), pengklentekan daun tebu P2 (60 hst) dan pemberian pupuk cair humakos $\mathrm{H} 2$ (8 liter/Ha) L3P2H2 yaitu 0,19 memberikan angka tertinggi dan ineteraksi pengolahan lahan L1 (Singkal), pengklentekan daun tebu P2 (60 hst) dan pemberian pupuk cair humakos $\mathrm{H} 3$ (12 liter/Ha) L1P2H3 yaitu 0,05 memberikan angka terendah.

\section{Luas Daun Spesifik}

Berdasarkan analisis ragam (Tabel 1), terhadap luas daun spesifik tanaman kedelai pada umur 1 dan 2 BST. Pada umur 1 BST menunjukkan bahwa perlakuan pengolahan lahan berpengaruh berbeda nyata. Perlakuan pengklentekan daun tebu dan perlakuan pemberian pupuk cair humakos berpengaruh tidak berbeda nyata. Pada interaksi pengolahan lahan dan pengklentekan daun tebu, interaksi pengolahan lahan dan pemberian pupuk cair humakos, interaksi pengolahan lahan, pengklentekan daun tebu dan pemberian pupuk cair humakos berpengaruh tidak berbeda nyata. Pada umur 2 BST perlakuan pengolahan lahan, perlakuan pengklentekan daun tebu dan perlakuan pemberian pupuk cair humakos berpengaruh tidak berbeda nyata. Pada interaksi pengolahan lahan dan pemberian pupuk cair humakos, interaksi pengklentekan daun tebu dan pemberian pupuk cair humakos, interaksi pengolahan lahan, pengklentekan daun tebu dan pemberian pupuk cair humakos juga berpengaruh tidak berbeda nyata. Sedangkan interaksi pengolahan lahan dan pengklentekan daun tebu berpengaruh berbeda nyata. Adapun rata-rata luas daun spesifik pada umur 1 BST yang dipengeruhi oleh perlakuan pengolahan lahan disajikan pada Tabel 4.

Tabel 4 menunjukkan bahwa perlakuan pengolahan lahan L1 (Singkal) yaitu 3,73 dan dan L2 (Singkal + Rotari) yaitu 3,41 tidak berbeda nyata tetapi berbeda nyata dengan pengolahan lahan L3 (Singkal + Rotari + Rotari) yaitu 4,63. Perlakuan pengolahan lahan L3 (Singkal + Rotari + Rotari) memiliki luas daun spesifik tertinggi dengan rata-rata yaitu 4,63. $\mathrm{Hal}$ ini diduga kandungan hara dalam tanah rendah yaitu unsur $\mathrm{N}$ yang berperan dalam meningkatkan pertumbuhan atau fase vegetatif dari tanaman. Menurut Bala dan Fagbayide (2009) dalam Santoso $d k k$. (2012), nitrogen berperanan penting dalam pertumbuhan suatu tanaman. Kekurangan nitrogen dapat menyebabkan tanaman menjadi kerdil dan ditandai 
dengan warna daun hijau pucat atau hijau kekuningan, klorosis pada daun serta terjadi nekrosis pada daun tua.

Tabel 4. Rata-rata Luas Daun Spesifik Umur 1 BST Yang Dipengaruhi Oleh Perlakuan Pengolahan Lahan.

Pengolahan Lahan

Luas Daun Spesifik

$\begin{array}{lll}\text { L1 } & 3,73 & \text { b } \\ \text { L2 } & 3,41 & \text { b } \\ \text { L3 } & 4,63 & \text { a }\end{array}$

Keterangan : Rata-rata yang diikuti huruf yang sama pada kolom menunjukkan berbeda nyata pada uji Duncun taraf 5\%.

Berdasarkan hasil analisis ragam (Tabel 1), terhadap luas daun spesifik tanaman kedelai menunjukkan bahwa interaksi pengolahan lahan dan pemberian pupuk cair humakos berpengaruh nyata terhadap variabel pengamatan luas daun spesifik umur 2 BST. Adapun rata-rata luas daun spesifik umur 2 BST yang dipengaruhi oleh interaksi pengolahan lahan dan pemberian pupuk cair humakos disajikan pada Tabel 5 .

Tabel 5. Rata-rata Interaksi Pengolahan Lahan Dan Pemberian Pupuk Cair Humakos Pada Variabel Pengamatan Luas Daun Spesifik Umur 2 BST.

\begin{tabular}{cccc}
\hline & H1 & H2 & H3 \\
\hline L1 & $12,83 \mathrm{ap}$ & $4,67 \mathrm{bp}$ & $4,06 \mathrm{bq}$ \\
L2 & $7,75 \mathrm{aq}$ & $4,74 \mathrm{bp}$ & $6,73 \mathrm{ap}$ \\
L3 & $6,14 \mathrm{aq}$ & $5,62 \mathrm{bq}$ & $5,46 \mathrm{bp}$ \\
\hline
\end{tabular}

Keterangan : Angka rata-rata pada baris yang sama yang dikuti oleh huruf yang sama a, b, c yang sama dan angka rata-rata pada kolom yang sama yang di ikuti huruf $p, q, r$ yang sama menunjukkan tidak berbeda nyata pada Uji DMRT $\%$.

Tabel 5. hasil rata-rata luas daun spesifik pada interaksi pengolahan lahan dan pemberian pupuk cair humakos setelah diuji lanjut DMRT 5\%. Interaksi perlakuan pengolahan lahan dan pemberian pupuk humakos pada rata-rata baris yang diikuti hururf a,b,c yang sama menunjukkan tidak berbeda nyata (L1H2) yaitu 4,67 dan (L1H3) yaitu 4,06 tidak berbeda nyata tetapi berbeda nyata pada interaksi (L1H1) yaitu 12,83 , interaksi (L2H1) yaitu 7,75 dan (L2H3) yaitu 6,73 tidak berbeda nyata tetapi berbeda nyata pada interaksi (L2H2) yaitu 4,74, interaksi (L3H2) yaitu 5,62 dan (L3H3) yaitu 5,46 tidak berbeda nyata tetapi berbeeda nyata pada interaksi (L3H1) yaitu 6,14. Sedangkan pada interaksi pengklentekan daun tebu dan pemberian pupuk cair humakos pada rata-rata kolom yang diikuti oleh huruf $\mathrm{p}, \mathrm{q}, \mathrm{r}$ yang sama menunjukkan tidak berbeda nyata interaksi (L2H1) yaitu 7,75 dan (L3H1) yaitu 6,14 tidak berbeda nyata tetapi berbeda nyata pada interaksi (L1H1) yaitu 12,83, pada interaksi (L1H2) yaitu 4,67 dan (L2H2) yaitu 4,74 tidak berbeda nyata tetapi berbeda nyata pada interaksi ( $\mathrm{L} 3 \mathrm{H} 2)$ yaitu 5,62, interaksi (L2H3) yaitu 6,73 dan (L3H3) yaitu 5,46 tidak berbeda nyata tetapi berbeda nyata pada interaksi (L1H3) yaitu 4,06. Hal ini dipengaruhi oleh ketersediaan unsur hara $\mathrm{N}$ (nitrogen). Unsur hara nitrogen berperan penting dalam pertumbuhan vegetatif tanaman dalam pembentukan akar batang dan daun. (Muchovej dan Newman, 2004).

Berdasarkan hasil analisis ragam Tabel 1, menunjukkan bahwa tidak ada pengaruh yang nyata pada interaksi pengolahan lahan, pengklentekan daun tebu dan pemberian pupuk 
cair humakos terhadap pengamatan luas daun spesifik umur 1 dan 2 BST. Adapun rata-rata luas daun spesifik umur 1 dan 2 BST yang disajikan pada Gambar 4.

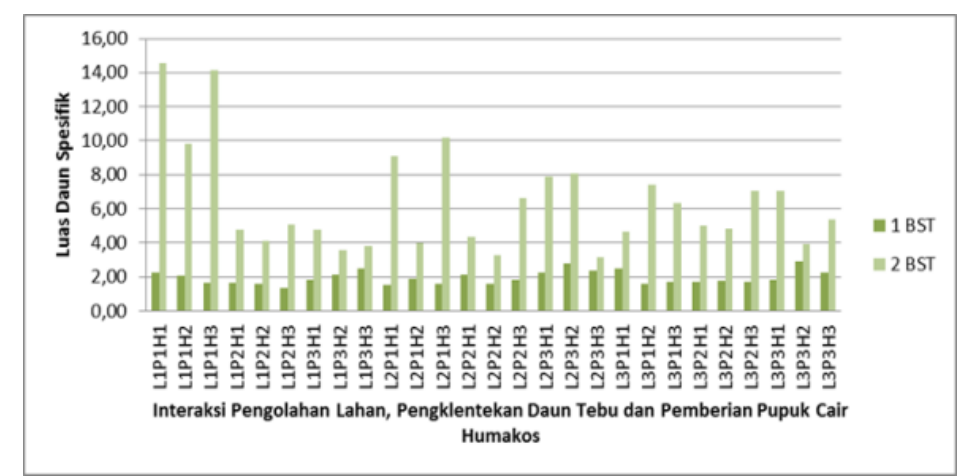

Gambar 4. Rata-rata interaksi pengolahan lahan, pengklentekan daun tebu dan pemberian pupuk cair humakos pada luas daun spesifik tanaman kedelai umur 1 dan 2 BST.

Gambar 4 rata-rata luas daun spesifik umur 1 BST tertinggi terdapat pada interaksi pengolahan lahan L3 (Singkal + Rotari + Rotari), pengklentekan daun tebu P3 (80 hst) dan pemberian pupuk cair humakos $\mathrm{H} 2$ (8 liter/Ha) L3P3H2 yaitu 2,99 dan rata-rata interaksi pengolahan lahan L1 (Singkal), pengklentekan daun tebu P2 (60 hst) dan pemberian pupuk cair humakos H1 (4 liter/Ha) L1P2H1 yaitu 1,32 memberikan angka terendah. Sedangkan rata-rata luas daun spesifik umur 2 BST tertinggi pada interaksi pengolahan lahan L1(Singkal), pengklentekan daun tebu P1 (45 hst) dan pemberian puuk cair humakos H1 (4 liter/Ha) L1P1H1 yaitu 14,54 dan rata-rata interaksi pengolahan lahan L2 (Singkal + Rotari), pengklentekan dau tebu P2 (umur $60 \mathrm{hst}$ ) dan pemberian pupuk cair humakos H2 (8 liter/Ha) L2P2H2 yaitu 3,33 memberikan angka terendah.

\section{Nilai Kesetaraan Lahan (NKL)}

Hasil analisis ragam (Tabel 1) terhadap nilai kesetaraan lahan (NKL) menunjukkan bahwa perlakuan pengolahan lahan dan perlakuan pengklentekan daun tebu tidak berbeda nyata, berpengaruh nyata pada perlakuan pemberian pupuk cair humakos. Sedangkan interaksi pengolahan lahan dan pengklentekan daun tebu, interaksi pengolahan lahan dan pemberian pupuk cair humakos, interaksi pengolahan lahan, pengklentekan daun tebu, dan pemberian pupuk cair humakos berpengaruh tidak berbeda nyata serta interaksi pengklentekan daun tebu dan pemerian pupuk cair humakos berbeda nyata pada parameter nilai kesetaraan lahan (NKL).

Rata-rata nilai kesetaraan lahan yang dipengaruhi oleh pemberian pupuk cair humakos dapat disajikan pada Tabel 6 .

Tabel 6. Rata-Rata Nilai Kesetaraan Lahan (NKL) Yang Dipengaruhi Oleh Pemberian Pupuk Cair Humakos.

Pemberian Pupuk Cair Humakos Nilai Kesetaraan Lahan

$\begin{array}{ll}\text { H1 } & 14.07 \mathrm{~b} \\ \mathrm{H} 2 & 13.95 \mathrm{~b} \\ \mathrm{H} 3 & 15.92 \mathrm{a}\end{array}$

Keterangan : Rata-rata yang diikuti huruf yang sama pada kolom menunjukkan berbeda tidak nyata pada uji Duncun taraf 5\%.

Tabel 6. menunjukkan bahwa perlakuan pemberian pupuk cair humakos H1 (4 liter/Ha) yaitu 14,07 dan $\mathrm{H} 2(8 \mathrm{liter} / \mathrm{Ha})$ yaitu 13,95 tidak berbeda nyata tetapi berbeda 
nyata dengan perlakuan pemberian pupuk humakos H3 (12 liter/Ha) yaitu 15,92. Perlakuan pemberian pupuk cair humakos $\mathrm{H} 3$ (120 ml humakos +6 liter air) memiliki nilai kesetaraan lahan tertinggi dengan rata-rata yaitu 15,92. Hal ini selaras dengan penelitian yang dilakukan oleh Bursruna et al (2018) dimana perimbangan pupuk (P2 $90 \mathrm{~kg}$ urea +2 ton organik) $1.75 \mathrm{~kg} / \mathrm{ha}$ memberikan hasil tertinggi terhadap rata-rata nilai kesetaraan lahan tumpangsari tebu kedelai.

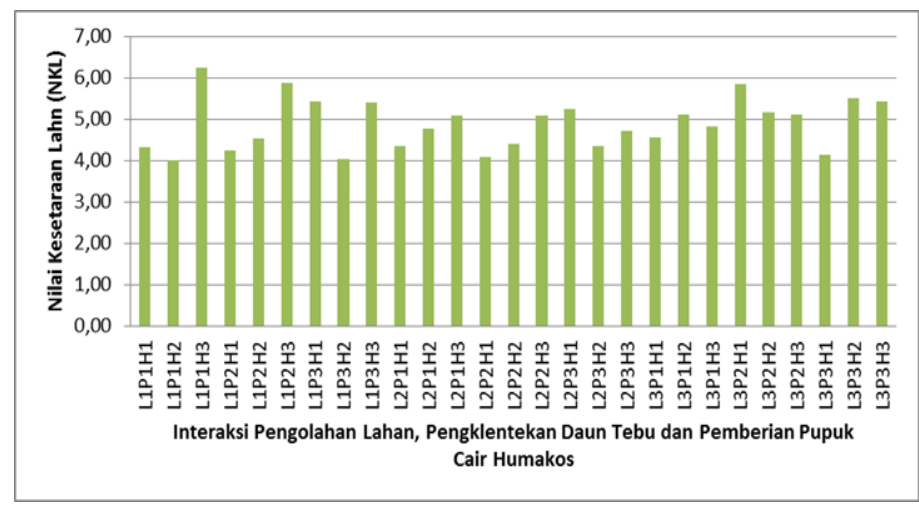

Gambar 5. Rata-rata interaksi pengolahan lahan, pengklentekan daun tebu dan pemberian pupuk cair humakos pada nilai kesetaraan lahan (NKL).

Pada interaksi pengolahan lahan, pengklentekan daun tebu dan pemberian pupuk cair humakos (L2P3H3) yaitu 6,23 memberikan angka tertinggi dan interaksi pengolahan lahan, pengklentekan daun tebu, dan pemberian pupuk cair humakos (L1P3H3) yaitu 4,01 memberikan angka terendah.

\section{Indeks Panen}

Hasil analisis ragam (Tabel 1) terhadap indeks panen menunjukkan bahwa perlakuan pengolahan lahan, perlakuan pengklentekan daun tebu, dan perlakuan pemberian pupuk cair humakos berbeda tidak nyata, berpengaruh nyata pada interaksi pengolahan lahan dan pemberian pupuk cair humakos. Sedangkan interaksi pengolahan lahan dan pemberian pupuk cair humakos, interaksi pengklentekan daun tebu dan pemberian pupuk cair humakos serta interaksi pengolahan lahan, pengklentekan daun tebu, dan pemberian pupuk cair humakos berpengaruh tidak berbeda nyata pada parameter indeks panen.

pupuk cair humakos $\mathrm{H} 1$ (4 liter/Ha) yaitu 1,91, pemberian pupuk cair humakos $\mathrm{H} 2$ (8 liter/Ha) yaitu 1,85 dan pemberian pupuk cair humakos $\mathrm{H} 3$ (12 liter/Ha) yaitu 1,87. Hasil tersebut menunjukkan bahwa setiap perlakuan pemberian pupuk cair humakos mengalami penurunan. Pemberian pupuk cair humakos H2 memiliki indeks panen terendah dibandingkan dengan pemberian pupuk cair humakos lainnya.

Rata-rata nilai indeks panen yang dipengaruhi oleh interaksi pengolahan lahan dan pemberian pupuk cair humakos disajikan pada Tabel 7.

Tabel 7. Rata-rata Indeks Panen Yang Dipengaruhi Oleh Interaksi Pengolahan Lahan Dan Pemberian Pupuk Cair Humakos.

\begin{tabular}{cccc}
\hline & H1 & H2 & H3 \\
\hline L1 & 2,05 ap & $1,54 \mathrm{bp}$ & $2,14 \mathrm{ap}$ \\
L2 & $1,79 \mathrm{aq}$ & $1,97 \mathrm{bq}$ & $1,79 \mathrm{aq}$ \\
L3 & $2,22 \mathrm{ap}$ & $1,75 \mathrm{bp}$ & $1,64 \mathrm{bq}$ \\
\hline
\end{tabular}


Keterangan: Angka rata-rata pada baris yang sama yang dikuti oleh huruf yang sama a, b, c yang sama dan angka rata-rata pada kolom yang sama yang di ikuti huruf p, q, r yang sama menunjukkan tidak berbeda nyata pada Uji DMRT 5\%.

Tabel 7. hasil rata-rata indeks panen pada interaksi pengolahan lahan dan humakos setelah diuji lanjut DMRT 5\%. Interaksi perlakuan pengklentekan daun tebu dan pemberian pupuk cair humakos pada rata-rata baris yang diikuti hururf a,b,c yang sama menunjukkan tidak berbeda nyata $(\mathrm{L} 1 \mathrm{H} 1)$ yaitu 2,05 dan $(\mathrm{L} 1 \mathrm{H} 3)$ yaitu 2,14 tidak berbeda nyata tetapi berbeda nyata pada interaksi ( $\mathrm{L} 1 \mathrm{H} 2)$ yaitu 1,54 , interaksi (L2H1) yaitu 1,79 dan (L2H3) yaitu 1,79 tidak berbeda nyata tetapi berbeda nyata pada interaksi (L2H2) yaitu 1,97, interaksi (L3H2) yaitu 1,75 dan (L3H3) yaitu 1,64 tidak berbeda nyata tetapi berbeda nyata pada interaksi (L3H1) yaitu 2,22. Sedangkan pada interaksi pengklentekan daun tebu dan pemberian pupuk cair humakos pada rata-rata kolom yang diikuti oleh huruf $\mathrm{p}, \mathrm{q}, \mathrm{r}$ yang sama menunjukkan tidak berbeda nyata interaksi (L1H1) yaitu 2,05 dan (L3H1) yaitu 2,22 tidak berbeda nyata tetapi berbeda nyata pada interaksi ( $22 \mathrm{H} 1)$ yaitu 1,79 , pada interaksi $(\mathrm{L} 1 \mathrm{H} 2)$ yaitu 1,54 dan $(\mathrm{L} 3 \mathrm{H} 2)$ tidak berbeda nyata tetapi berbeda nyata pada interaksi (L2H2) yaitu 1,97, pada interaksi ( $\mathrm{L} 3 \mathrm{H} 2)$ yaitu 1,79 dan $(\mathrm{L} 3 \mathrm{H} 3)$ yaitu 1,64 tidak berbeda nyata tetapi berbeda nyata pada interaksi $(\mathrm{L} 1 \mathrm{H} 3)$ yaitu 2,14 .

Hasil diatas selaras dengan penelitian yang dilakukan oleh Maulana. 2018. Hal ini diduga karena pengaruh curah hujan terhadap pertumbuhan tanaman. Penelitian Mabhaudhi dkk. (2013) menyatakan bahwa, curah hujan berpengaruh terhadap produktivitas kacang bambara. Curah hujan yang semakin tinggi akan meningkatkan produktivitas, kecuali pada masa generatif, karena dapat merontokkan bunga (Linneman dan Ali, 1993). Sitompul dan Guritno, (1995) menyatakan bahwa salah satu faktor dalam pertumbuhan tanaman yang menentukan hasil tanaman adalah biomassa tanaman, sehingga upaya peningkatan produktivitas tanaman dapat dicapai dengan peningkatan bobot biomassa tanaman. Biomassa merupakan semua bahan tanaman yang berasal dari hasil fotosintesis, serapan unsur hara dan air yang diolah melalui proses fotosintesis. Produksi biomassa mengakibatkan pertambahan berat tanaman yang diikuti dengan pertambahan ukuran lain yang dapat dinyatakan secara kuantitatif.

Adapun rata-rata nilai indeks panen yang dipengaruhi oleh interaksi pengolahan lahan, pengklentekan daun tebu dan pemberian pupuk cair humakos disajikan pada Gambar 6.

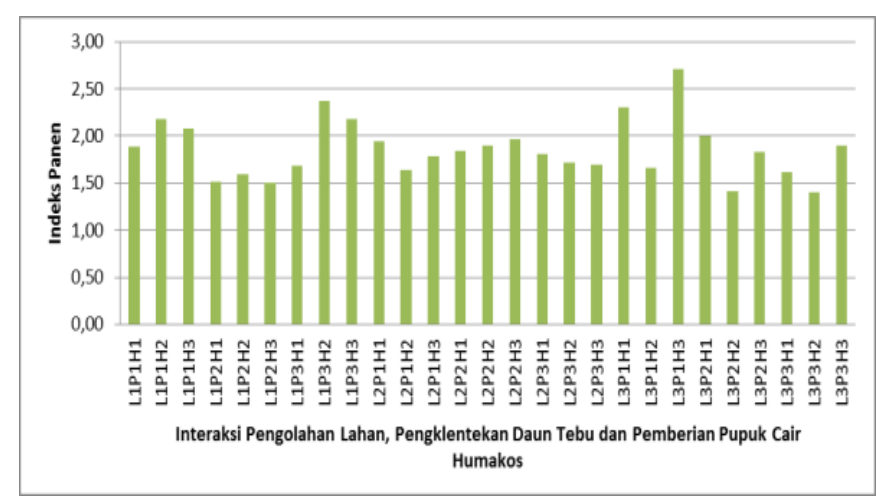

Gambar 6. Rata-rata interaksi pengolahan lahan, pengklentekan daun tebu, dan pemberian pupuk cair humakos pada variabel indeks panen.

Gambar 6. menunjukkan bahwa pengamatan indeks panen yang dipengaruhi oleh pengolahan lahan, pengklentekan daun tebu dan pemberian pupuk cair humakos (L3P1H3) 
yaitu 2,71 memberikan angka tertinggi dan pengolahan lahan, pengklentekan daun tebu dan pemberian pupuk cair humakos (L3P2H2) yaitu 1,41 memberikan angka terendah.

\section{KESIMPULAN}

Berdasarkan hasil analisis data dan pembahasan tentang "analisis pertumbuhan dan karakter fisiologi tanaman kedelai pada pengolahan lahan, pengklentekan daun tebu dan pemberian pupuk cair humakos pada tumpangsari tebu kedelai" maka dapat disimpulkan sebagai berikut:

1. Perlakuan pengolahan lahan berpengaruh pada luas daun spesifik umur 1 bst dan tetapi tidak berpengaruh pada variabel pengamatan lainnya.

2. Perlakuan pengklentekan daun tebu tidak berpengaruh pada semua variabel pengamatan.

3. Perlakuan pemberian pupuk cair humakos berpengaruh pada nilai kesetaraan lahan tetapi tidak berpengaruh pada variabel pengamatan lainnya.

4. Interaksi antara pengolahan lahan dan pengklentekan daun tebu berpengaruh pada laju asimilasi bersih dan tidak berpengaruh pada variabel pengamatan lainnya.

5. Interaksi antara pengolahan lahan dan pemberian pupuk cair humakos berpengaruh pada luas daun spesifik umur 2 bst dan indeks panen tetapi tidak berpengaruh pada variabel pengamatan lainnya.

6. Interaksi antara pengklentekan daun tebu dan humakos berpengaruh pada laju pertumbuhan tanaman, luas daun umur 1 bst, dan tidak berpengaruh pada variabel pengamatan lainnya.

7. Interaksi antara pengolahan lahan, pengklentekan daun tebu dan pemberian pupuk cair humakos tidak berpengaruh pada semua variabel pengamatan.

\section{DAFTAR PUSTAKA}

Adisarwanto, T. 2014. Kedelai tropika produktivitas 3 ton/ha. Penebar Swadaya. Jakarta.

Andrianto, T. T dan N. Indarto. 2004. Budidaya dan Analisis Usaha Tani; Kedelai, Kacang Hijau, Kacang Panjang. Cetakan Pertama. Penerbit Absolut, Yogyakarta. Hal. 9-92. Dalam Skripsi M. Ikmal Tawakkal. P. 2009. Respon Pertumbuhan dan Hasil Produksi Beberapa Varietas Kedelai (Glycine Max L) Terhadap Pemberian Pupuk Kandang Kotoran Sapi. Universitas Sumatera Utara. Medan.

Dompasa, S. 2014. Profil Usahatani Pola Penanaman Tumpang Sari Di Desa Sea Kecamatan Pineleng. Universitas Sam Ratulangi, Manado.

Dwidjoseputro. D. 2000. Pengantar Fisiologi Tumbuhan. Gramedia Utama. Jakarta.

Maulana, M. R., Umarie , I., Suroso, B., dan Jalil, A. 2018. Analisis Karakteristik Fisiologi dan Pertumbuhan Tanaman Kedelai (Glycine max L) terhadap Perimbangan Pupuk dan Populasi Tanaman pada Sistem Tumpang sari Tebu Kedelai. Journal of Undergraduate Thesis, Universitas Muhammadiyah jember. 1-56

Muchovej, R.M and P. R. Newman. 2004. Nitrogen fertilization of sugarcane on a sandy soil: I. Yield and leaf nutrient composition. J. American Society Sugar Cane Technologists. 5 (24):210-224.

Sitompul SM, Guritno B. 1995. Analisis pertumbuhan tanaman. Yogyakarta (ID): Gadjah Mada University Press. 412 hal.

Taufik, A., T. Sundari. 2012. Respons tanaman kedelai terhadap lingkungan tumbuh. Buletin Palawija 23:13-26. 